Fei LI, PhD

Email:emlifei@bupt.edu.cn

Professor Yan CHEN, PhD

Email: chen_yan@bupt.edu.cn (Corresponding author)

Liyezi ZHANG, PhD

School of Economics and Management

Beijing University of Posts and Telecommunications

Email:zhanglyz@126.com

Lecturer Lavinia DUDAŞ, PhD

Faculty of Economic Sciences, Computer Science and Engineering

"Vasile Goldis" Western University of Arad

Email: laviniamustea@gmail.com

\title{
HOW DO CROSS-BORDER MERGERS AND ACQUISITIONS \\ IMPROVE INNOVATION QUALITY IN EMERGING MARKET \\ MULTINATIONAL ENTERPRISES? AN INTERACTION PERSPECTIVE BASED ON NETWORK BALANCE AND DIGITAL GAPS
}

\begin{abstract}
Received multinational enterprise theories are challenged by the progress of digitization. How do emerging-market multinational enterprises utilize cross-border merger and acquisitions to improve innovation quality in the digital economy era? To shed light on this question, we combined the literature on network balance with a digital gap perspective. We conducted a bootstrap repeated-sampling analysis of a sample of 146 overseas mergers and acquisitions conducted by Chinese-listed manufacturing companies between 2001 and2016. We found that network-embedding balance has a positive impact on the quality of post-M\&A domestic and international innovation, and that China's digital development has not promoted a positive correlation between network balance and innovation quality. In the presence of a wide digital gap between a firm's home and host countries, network balance can significantly improve the quality of post-overseas $M \& A$ domestic innovation; conversely, when this gap is narrow, a firm can use the interaction between network balance and the host country's digital level to improve the quality of its international innovation. Chinese manufacturing enterprises can enhance their ability to obtain highly complex tacit knowledge by increasing their digital level. In this paper, we explain a new mechanism that digital economy emerging-market multinational enterprises can use to construct a balanced network and thus gain global innovation advantages.

Keywords: innovation network, digital economy, emerging-market multinational enterprises, cross-border $M \& A s$, innovation quality.
\end{abstract}

JEL classification: F23, 032

DOI: $10.24818 / 18423264 / 53.3 .19 .12$ 
Fei Li, Yan Chen, Liyezi Zhang, Lavinia Dudaş

\section{Introduction}

The numbers of merger and acquisition (M\&A) activities conducted by emerging market multinationals (EMNEs) have considerably increased in the last few decades (Rao-Nicholson et al., 2016; Liu and Meyer, 2018). EMNEs predominantly pursue cross-border M\&As to gain access to developed economies, with the US, Canada, and Europe being primary destinations due to their leading technology and innovation, as well as lucrative markets (Caiazza et al., 2017; Liu et al., 2018; Liu and Vrontis, 2017; Rao-Nicholson and Salaber, 2015). Acquiring firms can gain access to the host countries' research and development resources, which, in turn, can accelerate the diffusion of knowledge in their home countries and the spillover of technology to local industries (Yoon and Lee, 2016). Chinese overseas M\&As are on the rise and constitute an important example of how companies from emerging economies venture into advanced ones (Liu and Vrontis, 2017; Xing et al., 2017). According to data drawn from the Chinese Commerce of Ministry, China's outward foreign direct investment (OFDI) amounted to US\$158.29 billion in 2017, accounting for more than $10 \%$ of the global share for two consecutive years. According to Thomson Reuters, the proportion of overseas M\&As in China's total OFDI increased from $37.37 \%$ in 2015 to $75.57 \%$ in 2017, meaning that overseas M\&As are the dominant mode of international market entry of Chinese MNEs. Overseas M\&As motivated by the sourcing of technology are still growing. In recent years, digitization has progressed rapidly in emerging-market countries. To take China again as an example, its digital economy grew by $17.24 \%$ in 2017 , with that sector's share of GDP rising to $32.28 \%$. The integration of highly complex and strongly non-transferable tacit knowledge is the core of enterprise strategies aimed at increasing innovation and competitiveness. In essence, digitization can improve the standardization, simplification, openness, and transferability of tacit knowledge. Therefore, researchers should study whether and how digital development can help EMNEs to acquire highly complex overseas innovation resources in order to improve their innovation quality.

The rise of the digital economy and the spread of EMNEs are the two most profound recent changes in the field of international commerce; these developments have challenged traditional foundational theory involving transnational M\&As and foreign investment. The digital paradigm shift has changed the processes, governance modes, and driving forces of value creation in international business - thus profoundly reshaping the connotations of competitive advantage for MNEs (Alcácer et al.,2016). Digitization has changed the ways in which enterprises seek to gain competitive advantage; instead of acquiring complex knowledge embedded in physical assets, they now engage in simplification, standardization, and co-ownership of services and networks (Liang et al.,2018). The term firm-specific advantage refers not only to the direct benefits but also to the advantages that can be acquired from various outside networks (Bharadwajet al.,2013).In previous studies based on network theory, researchers have suggested that M\&As are not isolated bilateral relationships (Wang and Zajac, 2007), as they involve network embeddedness (Lin et al., 2009).Patel et al. (2014) found that, for

DOI: $10.24818 / 18423264 / 53.3 .19 .12$ 
How Do Cross-Border Mergers and Acquisitions Improve Innovation Quality in Emerging Market Multinational Enterprises? An Interaction Perspective Based on Network Balance and Digital Gaps

MNEs, a balance between domestic and foreign networks contributes to innovation and increases product internationalization speed. However, little research has been conducted on how the interaction between digitization and innovation-network equilibrium affects the internal mechanism of the cultivation of competitive advantage through overseas M\&As. There is a lack of research on whether regional bundling effects(Iurkov and Benito, 2018)enhance the competitive advantage of companies(measured in terms of domestic and international innovation quality) after they engage in overseas M\&A. The main goal of this paper is to determine whether enterprises can use networks only to cultivate domestic innovation or also to improve international innovation. Williamson (2016) pointed out that emerging markets are more likely than others to break off their dependence on old technological paradigms - which, in turn, accelerates digital innovation across existing solutions and creates a base of Big Data. Therefore, when EMNEs access developed country markets, they must examine both the host countries' potential to provide digital-location advantages and the influence that their own emerging markets have on their ability to make use of their home countries' digital advantages. However, there is a lack of research based on the digital divide between host and home countries to examine the moderating effects that network balance could have on the quality of overseas innovation due to M\&As.

Through this study, we contribute to the literature in four ways. Firstly, we shed light on cross-border M\&A strategies with digital characteristics. Instead of examining only the firm-specific advantages of EMNEs in the digital economy, we used the interactions of digital gaps and network balance to explore a new mechanism in which such enterprises construct balanced networks to realize global innovation advantages in the digital economy. Secondly, instead of relying on overseas M\&A theory (in which the relationship between isolated M\&A parties is thought of as purely binary), we started from global network embedding theory and focussed on how the balance between an acquiring firm's domestic and foreign networks enhances its global innovation advantage after it has engaged in an overseas M\&A. Thirdly, we enhance the understanding of the liabilities of emergingness in the era of digitization, we examined both the developed countries' ability to provide a digital location advantage and the emerging markets'influence on their home countries' digital advantage. Finally, regarding the digital gap between host and home countries, we explored how the differences and similarities in digital-location advantages between the host and home countries can moderate the influence of network balance on overseas M\&As' innovation quality.

\section{Theory and Hypothesis}

Innovation networks are important ways in which various enterprises can go beyond their organizational boundaries by acquiring external technological and

DOI: 10.24818/18423264/53.3.19.12 
innovation resources (Freeman, 1991). Recently, firms have been dissolving these boundaries to foster learning activities across firms and even across industries, at both the national and international scales (Alguezaui and Filieri, 2010). According to latecomer-firm theory, due to the increasing complexity and global dispersal of knowledge, enterprises from emerging countries must attempt to catch up by embedding themselves in global innovation networks (Herrigel et al., 2013). Because such enterprises have limited time and resources for overseas innovation, they must determine whether they should give priority to local or foreign network cooperation. In addition to the liability of foreignness, EMNEs must overcome the fact that they are often among the first generation of companies from their home countries to venture abroad. These firms have little experience in cross-border activities or in interacting with enterprises from other local industrial networks; thus, these emerging-market firms are constrained in multiple ways (Graebneret al.,2017). However, foreign partners can enable the acquiring firms to obtain business knowledge from specific markets for use in innovation. Foreign networks provide key institutional and business knowledge of the global market - which the firms can then use for post-M\&A innovation - but foreign-network embeddedness requires significant time and resources. Firms can use local networks to accelerate their innovation processes by utilizing highly efficient adjacent resources, but local partners cannot provide the heterogeneous global knowledge that firms need for innovation. Therefore, the dilemma lies in whether, to improve post-merger innovation, MNEs should prioritize the obtainment of international knowledge through foreign partners or the achievement of proximity-based efficiency through local partners. Importantly, should an enterprise over-embed itself in a single network, the result will be information redundancy, which will have serious effects such as innovation imitation. At the same time, maintaining the network-embedding relationship between enterprises inevitably causes problems in coordinating the interests of all the parties in the network; such problems cause enterprises to pay excessive coordination costs and can crowd out innovation.

Based on the early conceptualization of network efficiency and in an attempt to create a balance between network participants, Coombs et al. (2009) found that a geographically balanced network contributes to the development of new products; it does so largely because it increases the diversity and efficiency of a company's knowledge-search process. Per network theory, a balanced network configuration integrates all kinds of basic knowledge and thus minimizes both coordination costs and knowledge-transfer difficulty; this improves the quality of innovation. Network diversity contributes to the acquisition of diverse knowledge resources pertaining to broad technological developments, thus providing sufficiently explicit and relevant knowledge (Lavie and Miller,2008). Focussing only either on local or foreign sources of innovation may lead to incomplete innovation knowledge or, even worse, to an imperfect understanding of a host country's culture and institutions, which is not conducive to improved innovation quality. Thus, we propose the first two hypotheses: 
How Do Cross-Border Mergers and Acquisitions Improve Innovation Quality in Emerging Market Multinational Enterprises? An Interaction Perspective Based on Network Balance and Digital Gaps

Hypothesis 1a: The balance of network embeddedness is positively correlated to the domestic innovation quality of Chinese enterprises that have engaged in overseas M\&As.

Hypothesis 1b: The balance of network embeddedness is positively correlated to the international innovation quality of Chinese enterprises that have engaged in overseas M\&As.

Digitization is the process by which complex information is transformed into standard, measurable data by means of information and communication technologies. A digital infrastructure supports digitization (Nambisan,2018). Traditional location theory is mainly concerned with the need for enterprises to minimize transportation costs while achieving economies of scale. However, the digital economy requires new conceptualizations of location advantage. When engaging in overseas M\&As,MNEs should consider not only aspects of traditional location advantage (e.g., transportation costs, human resources, and technological endowments) but also the convenience gained through digital advantage. Digitization transforms firm-specific advantages; instead of retaining complex knowledge embedded in physical assets, digitization enables firms to simplify, standardize, service, and share the knowledge that is embedded in digital platforms. Instead of being owned by a single enterprise, the advantage is dispersed throughout a network and can be accessed by each enterprise within it(Broutherset al., 2018). By acquiring flagship positions through overseas M\&As, enterprises can join these networks, thereby gaining competitive advantages and improving their innovation quality.

Due to digitization, enterprises within a network are linked not by capital flow (as they traditionally have been) but by the flow of information and knowledge(Pezderka, 2011). In the digitally globalized world, the flow of information occupies the core position for several reasons (Manyikaet al., 2016). Firstly, digitization eliminates the restrictions of physical space, so that enterprises that engage in overseas M\&As no longer need to physically exchange information; instead, they can immediately disseminate information through the Internet (Yooet al., 2016). This can reduce the costs involved in coordinating between partners within the innovation network and can reduce the maintenance costs related to acquiring firms in the network. Secondly, the digital economy creates space into a set of digital information flows(Kobrin,2017). As a result, flows of information and knowledge have taken the place of those of capital. The rapid flow of information within a network enables the more effective allocation of resources (El and Pereira,2016),improves knowledge and resource heterogeneity, increases the usefulness of new products and services, and promotes innovation. Finally, due todigitization, enterprises can transfer information and knowledge through standard

DOI: $10.24818 / 18423264 / 53.3 .19 .12$ 
global protocols (Rai and Pavlou,2012); this can enhance the transferability of network knowledge and promote technological innovation. Therefore, in this paper, we argue that, in the wake of overseas M\&As, digitization positively moderates the correlation between network-embedding equilibrium and innovation quality. Thus, we propose hypotheses $2 \mathrm{a}$ and $2 \mathrm{~b}$ :

Hypothesis 2a:the degree of digitization has a positive moderating effect on the correlation between network balance and domestic innovation quality for Chinese enterprises that have engaged in overseas M\&As.

Hypothesis 2b: the degree of digitization has a positive moderating effect on the correlation between network balance and international innovation quality for Chinese enterprises that have engaged in overseas M\&As.

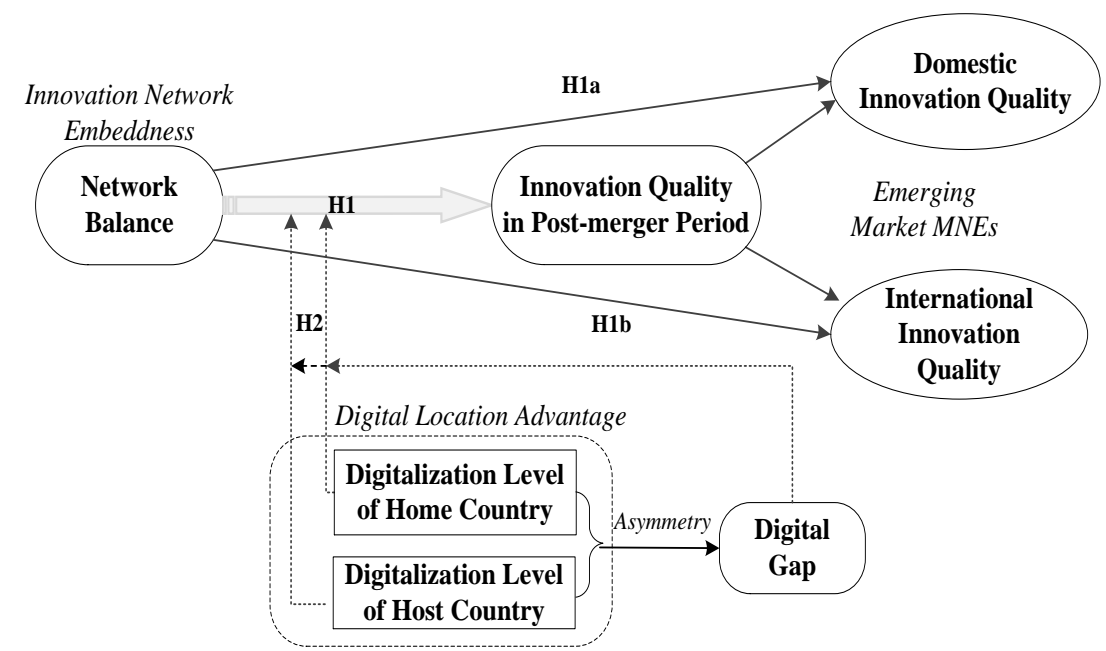

Figure 1. Research framework

\section{Research Method}

\subsection{Samples}

This study's data were drawn from the BvD's Zephyr, a globally authoritative M\&A database. The sample time frame goes from January 2001 to June 2016. We chose the starting point in January 2001 because of the significant increase of overseas investment witnessed in China after its accession to the World Trade Organization. We chose the endpoint of June 2016 to account for the lagging of innovation output in the wake of overseas M\&As; a lag of at least two years is needed for a test window. According to the BvD's Zephyr database, 722 overseas M\&A events involving Chinese-listed companies were completed during the selected time frame. Following Puranam et al.(2009), we screened for enterprises the main business of which was manufacturing, in accordance with the standard industry classification Codes 20-39. This yielded 372 events. Lastly, we pored over the announcements of these M\&As and discarded those that had not been driven by the sourcing of technology. Thus, the final sample included 146 events. 
How Do Cross-Border Mergers and Acquisitions Improve Innovation Quality in Emerging Market Multinational Enterprises? An Interaction Perspective Based on Network Balance and Digital Gaps

\subsection{Measurement}

\section{(1) Dependent variables}

The dependent variables are the acquiring firms' post overseas-M\&A domestic and international innovation quality. Drawing on Akcigit et al. [30], we used the patent knowledge-breadth method to measure innovation quality. We collected the IPC (International Patent Classification) numbers of the acquiring firms' domestic and foreign patents from China's State Intellectual Property Office and the World Intellectual Property Organization websites, respectively. Based on the Herfindahl-Herchmann index at the major group level, we calculated the patent breadth as follows:

$$
\text { Patent_knowledge } e_{n t, \text { type }}=1-\Sigma \alpha^{2}
$$

In this equation, $\alpha$ indicates the proportion of each major group in the patent classification number. Larger values of Patent_knowledge nt,type $_{\text {indicate bigger }}$ differences between the patent-classification numbers of the groups- i.e. a wider breadth of knowledge indicates a higher quality of patent.

However, as the innovative output of an acquiring firm lags two to five years behind the completion of its M\&A, when measuring the quality of a firm's innovation, we drew on Makriet al.(2010) and selected patent data for two years after each M\&A. To test the reliability of our selection of measurement intervals, we collected patent data for three years after each M\&A and measured innovation quality for 103 samples in which the M\&A had been completed before 30 June 2015. Cohen's $\kappa$ for the two-year- and three-year-lagged groups was 0.513 ( $p$ < 0.001 ), which was higher than the acceptable threshold of 0.4 . Reliability (using Cronbach's $\alpha$ ) was $0.773(p<0.001)$, which was higher than the standard threshold of 0.7. This proved that the two-year measurement interval for innovation quality had acceptable consistency and reliability. As the selection of a two-year lag also improved the sample size of this empirical research, we used it in this paper.

\section{(2) Independent variable}

This paper's independent variable is the balance of network embeddedness. Patent cooperation is a widely used tool in research on innovation networks. Various types of patent partners contribute to product-development processes and knowledge bases in distinct ways. Therefore, we used patent-cooperation data to construct domestic and foreign innovation networks. We divided the patent partners into three groups: (1) universities, (2) supply-chain enterprises, and (3) competitive enterprises, following the categories outlined by Patel et al.(2014). We calculated an acquiring firm's local and foreign network efficiency as, respectively,

Local netwaork efficiency $=\frac{1-\sum_{i, \text { local }}^{m=3}\left(\text { weight }_{i, \text { local }} * \text { count }_{i, \text { local }}\right)^{2}}{\text { Total counts local }}$

DOI: 10.24818/18423264/53.3.19.12 
Fei Li, Yan Chen, Liyezi Zhang, Lavinia Dudaş

Foreign netwaork efficiency $=\frac{1-\sum_{i, \text { foreign }}^{m=3}\left(\text { weight }_{i, \text { foreign }} * \text { count }_{i, \text { foreign }}\right)^{2}}{\text { Total counts }{ }_{\text {foreign }}}$

In these equations, count $t_{i, l o c a l}$ represents the number of domestic partners for the type- $i$ patents for which an acquiring firm applied within two years of the M\&A; count $_{i \text {,forgein }}$ represents the number of foreign partners of type $i$; Totalcounts local is the total number of domestic partners. Totalcounts foreign $_{\text {in }}$ is the total number of foreign partners; weighti,local is the domestic partner's proportion of the total domestic cooperation for type $i$; and weight $t_{i f o r e i g n}$ is the foreign partner's proportion of the total foreign cooperation for type $i$.

We then calculated the balance between domestic and foreign networks as follows:

Network Balance $=1-\mid$ local network efficiency - foreign network efficiency $\mid$

(3) Moderating variable

Digitization is the process by which complex information is transformed into standard, measurable data by means of information and communication technologies. A digital infrastructure supports digitization (Nambisan, 2018). The moderating variables in this study are the host and home countries'digitization levels, which we measured using the Internet-penetration rate in each country one year prior to the M\&A-i.e., the proportion of each country's population that used the Internet.

\section{(4) Control variables}

This study's enterprise-level control variables are transaction amount, management cost, and enterprise assets. Transaction amount is the value of the overseas M\&A, management cost is the average value of management expenses in the three years before the M\&A, and enterprise assets represent the average value of the firm's total assets in the same period. The national-level control variables are home-country GDP, host-country GDP, and Hofstede's cultural distance. The GDP values are the average GDPs of the host or home country in the three years prior to the M\&A(using a 2010-constant US dollar); cultural distance (a widely used measure) was measured between China and the host countries.

We detail each variable's categories, names, symbols, definitions, and data sources in Table 1. The variables' descriptive statistics and correlation details are shown in Table 2.

DOI: $10.24818 / 18423264 / 53.3 .19 .12$ 
How Do Cross-Border Mergers and Acquisitions Improve Innovation Quality in Emerging Market Multinational Enterprises? An Interaction Perspective Based on Network Balance and Digital Gaps

Table 1. Variables and measurement

\begin{tabular}{|c|c|c|c|}
\hline & Variable name & $\begin{array}{l}\text { Variable } \\
\text { symbol }\end{array}$ & Data sources \\
\hline \multirow[t]{2}{*}{$\begin{array}{l}\text { Dependent } \\
\text { Variable }\end{array}$} & $\begin{array}{c}\text { Domestic innovation } \\
\text { quality }\end{array}$ & Dquality & Baiten Patent Database \\
\hline & $\begin{array}{c}\text { International } \\
\text { innovation quality }\end{array}$ & Fquality & $\begin{array}{l}\text { Baiten Patent Database } \\
\text { (www.patexplorer.com) }\end{array}$ \\
\hline Independent & Network balance & GNB & Baiten Patent Database \\
\hline \multirow{2}{*}{$\begin{array}{l}\text { Moderate } \\
\text { Variable }\end{array}$} & $\begin{array}{l}\text { Internet penetration } \\
\text { rate of home country }\end{array}$ & $\mathrm{DU}$ & World bank Database \\
\hline & $\begin{array}{l}\text { Internet penetration } \\
\text { rate of host country }\end{array}$ & FU & World bank Database \\
\hline \multirow{6}{*}{$\begin{array}{l}\text { Control } \\
\text { Variable }\end{array}$} & Deal value & DV & BvD Zephyr Database \\
\hline & Management cost & $\mathrm{MC}$ & $\begin{array}{c}\text { Annual report of listed } \\
\text { companies }\end{array}$ \\
\hline & Asset & AS & $\begin{array}{c}\text { Annual report of listed } \\
\text { companies }\end{array}$ \\
\hline & $\begin{array}{l}\text { GDP of Home } \\
\text { country }\end{array}$ & DGDP & World bank Database \\
\hline & GDP of Host country & FGDP & World bank Database \\
\hline & Cultural distance & CD & Hofstede-insights \\
\hline
\end{tabular}

\section{Results}

\subsection{Models}

To test the hypotheses, we constructed 12 models. Model 1 contained independent and control variables: $\beta_{0}$ is the intercept term, $\beta_{1}$ is the regression coefficient of independent variable GNB and $\varepsilon$ is the random-perturbation term. We created the regression coefficients of Model 2, $\beta_{2}$ and $\beta_{3}$, by adding adjustment variables $D U$ and $F U$. For Models 3 and4, we added two interaction terms to the adjustment and independent variables, the regression coefficients for these models are $\beta_{4}$ and $\beta_{5}$, respectively.

$$
\begin{array}{cc}
\text { Quality }=\beta_{0}+\beta_{1} G N B+\beta_{2-7} \sum \text { controls }+\varepsilon & \text { Model (1) } \\
\text { Quality }=\beta_{0}+\beta_{1} G N B+\beta_{2} D U+\beta_{3} F U+\beta_{4-9} \sum \text { controls }+\varepsilon & \text { Model (2) } \\
\text { Quality }=\beta_{0}+\beta_{1} G N B+\beta_{2} D U+\beta_{3} F U+\beta_{4} D U \times G N B+\beta_{5-10} \sum \text { controls }+\varepsilon & \text { Model (3) } \\
\text { Quality }=\beta_{0}+\beta_{1} G N B+\beta_{2} D U+\beta_{3} F U+\beta_{4} F U \times G N B+\beta_{5-10} \text { controls }+\varepsilon & \text { Model (4) }
\end{array}
$$

For Models 5 to 8 , we divided the samples according to the digitization gap and tested the hypotheses by grouping. For Models 9 to 12, we divided the samples according to the knowledge complexity of the M\&As and tested the hypotheses in separate groups. We also divided quality into domestic and foreign versions.

DOI: $10.24818 / 18423264 / 53.3 .19 .12$ 


\subsection{Empirical results for the full sample}

Table 3 shows the empirical results for post-overseas M\&A innovation quality from the perspective of the interaction between digitization and network embedding. The network balance is positively correlated with the quality of the Chinese acquirers'domestic and international innovation in the post-merger period. Thus, Hypotheses 1a and $1 \mathrm{~b}$ are supported.

Home-country digitization level has a significant and negative moderating effect on the correlation between network balance and domestic innovation quality, buthost-country digitization level has no significant influence on this relationship $(\beta=-0.004, p>0.1)$. Thus, Hypothesis $2 \mathrm{a}$ is not supported.

Home and host country digitization levels have significant and positive moderating effects on the correlation between network balance and the quality of the Chinese enterprises' post-overseas M\&A domestic and international innovation. Thus, Hypothesis $2 \mathrm{~b}$ is supported.

Figure 2 shows that network balance has a significant positive impact on both domestic and international innovation quality. The contour offset can be seen in the left portion of Figure 2. As the home country's digitization level increases, the impact of network balance on domestic innovation quality weakens. This strengthens the support for this correlation. In recent years, China's digital technology has mostly been used in the service industry-particularly in the development of e-commerce. Thus, Internet technology and the service industry are becoming increasingly connected. In contrast, the integration of digitization into the real economy and the manufacturing industry has been neither rapid nor widespread, as it is difficult for manufacturing enterprises to access such networks by taking advantage of China's digitization. Thus, the competitive advantage of being in a network cannot effectively improve the quality of firms' overseas M\&A innovations. This may be related to the lack of support for Hypothesis $2 \mathrm{a}$.
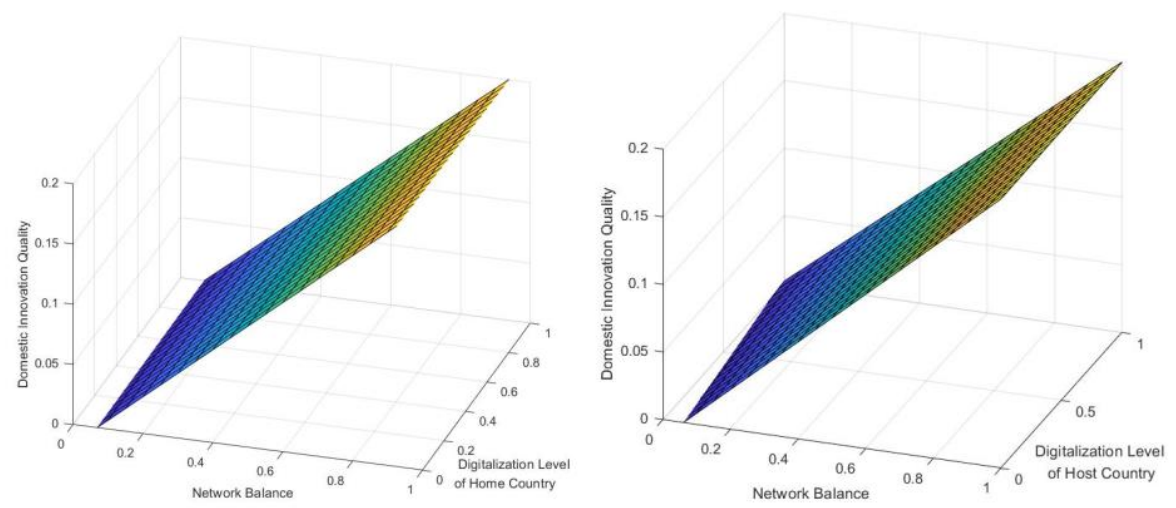

DOI: $10.24818 / 18423264 / 53.3 .19 .12$ 
How Do Cross-Border Mergers and Acquisitions Improve Innovation Quality in Emerging Market Multinational Enterprises? An Interaction Perspective Based on Network Balance and Digital Gaps
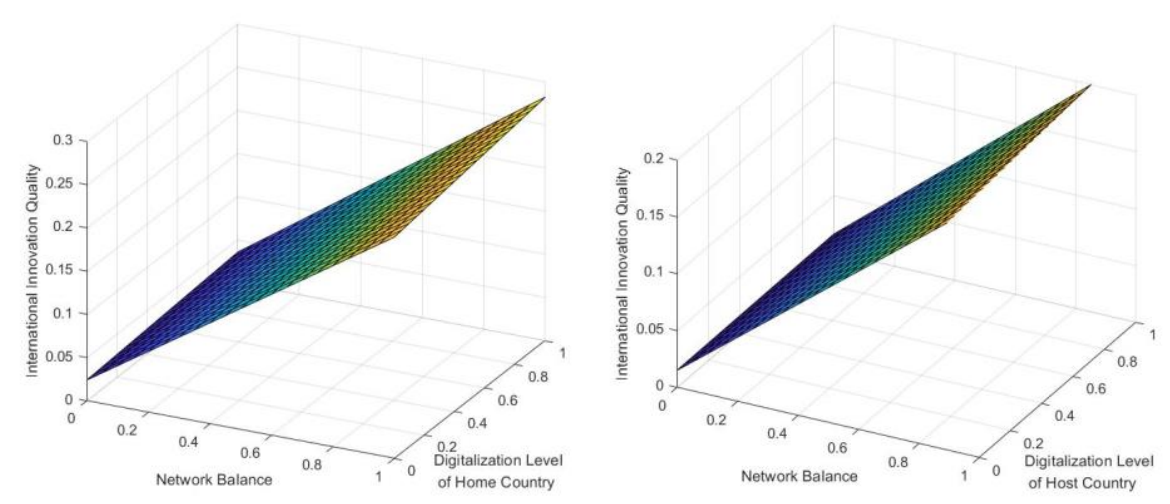

Figure 2. The moderate effects of digitalization

\subsection{Empirical results of subgroup samples \\ (1)Grouping by digital gap degree between host and home countries}

In this paper, we defined the digital gap as the absolute value of the difference in Internet accessibility between the host and home countries (in terms of Internet-penetration rate). We divided the sample into two groups according to the median digital gap. The results indicate that a wide digital gap, in combination with a balance between the acquiring firm's domestic and foreign networks, promotes post-overseas M\&A domestic innovation. When the digital gap is narrow, however, such network balance promotes international innovation, and the host country's degree of digitization significantly and positively moderates that correlation. There are several reasons for this. Firstly, when the digital gap is wide, network balance only allows for the incubation of domestic innovation centres; conversely, when the digital gap is narrow, the network balance can enable the incubation of global innovation. Secondly, a high degree of digitization means that an enterprise's competitive advantage is dispersed within its network, which makes that network complementary and modular.

DOI: $10.24818 / 18423264 / 53.3 .19 .12$ 
Fei Li, Yan Chen, Liyezi Zhang, Lavinia Dudaş

Table 2. Descriptive statistics and correlation

\begin{tabular}{|c|c|c|c|c|c|c|c|c|c|c|c|}
\hline & 1 & 2 & 3 & 4 & 5 & 6 & 7 & 8 & 9 & 10 & 11 \\
\hline Dquality & 1 & & & & & & & & & & \\
\hline Fquality & 0.174 & 1 & & & & & & & & & \\
\hline GNB & 0.314 & 0.378 & 1 & & & & & & & & \\
\hline $\mathrm{DU}$ & 0.227 & 0.11 & -0.047 & 1 & & & & & & & \\
\hline $\mathrm{FU}$ & 0.171 & 0.081 & 0.11 & 0.45 & 1 & & & & & & \\
\hline DV & -0.025 & -0.014 & -0.093 & -0.035 & 0.044 & 1 & & & & & \\
\hline MC & 0.276 & 0.231 & 0.281 & 0.145 & 0.172 & 0.066 & 1 & & & & \\
\hline AS & 0.221 & 0.307 & 0.386 & 0.109 & 0.177 & 0.041 & 0.754 & 1 & & & \\
\hline DGDP & 0.21 & 0.089 & -0.051 & 0.985 & 0.445 & -0.057 & 0.133 & 0.114 & 1 & & \\
\hline FGDP & 0.035 & -0.131 & -0.027 & 0.08 & 0.028 & -0.033 & -0.106 & -0.089 & 0.086 & 1 & \\
\hline $\mathrm{CD}$ & 0.127 & $-6.62 \mathrm{E}-03$ & 0.125 & 0.0743 & 0.430 & 0.06 & 0.042 & 0.062 & 0.069 & 0.114 & 1 \\
\hline Mean & 0.691 & 0.133 & 0.263 & 35.048 & 72.31 & 3596802 & $1.91 \mathrm{E}+08$ & $3.51 \mathrm{E}+10$ & $6.09 \mathrm{E}+12$ & $4.16 \mathrm{E}+12$ & 2.376 \\
\hline $\begin{array}{l}\text { Std. } \\
\text { Dev. }\end{array}$ & 0.337 & 0.293 & 0.404 & 15.178 & 16.977 & 25196418 & $2.89 \mathrm{E}+08$ & $2.84 \mathrm{E}+11$ & $1.86 \mathrm{E}+12$ & $5.41 \mathrm{E}+12$ & 1.226 \\
\hline
\end{tabular}

Table 3. Empirical results of full sample

\begin{tabular}{|c|c|c|c|c|c|c|c|c|}
\hline & \multicolumn{4}{|c|}{ Domestic innovation quality } & \multicolumn{4}{|c|}{ International innovation quality } \\
\hline & Model 1 & Model 2 & Model 3 & Model 4 & Model 5 & Model 6 & Model 7 & Model 8 \\
\hline GNB & $\begin{array}{l}0.230 * * * \\
(-3.091)\end{array}$ & $\begin{array}{l}0.231^{* * * *} \\
(-3.063)\end{array}$ & $\begin{array}{l}0.212 * * * \\
(-2.883)\end{array}$ & $\begin{array}{l}0.233 * * * \\
(-3.084)\end{array}$ & $\begin{array}{l}0.216 * * * \\
(-3.646)\end{array}$ & $\begin{array}{l}0.213 * * * \\
(-3.566)\end{array}$ & $\begin{array}{l}0.232 * * * \\
(-4.068)\end{array}$ & $\begin{array}{c}0.207 * * * \\
(-3.511)\end{array}$ \\
\hline DU & & $\begin{array}{c}0.013 \\
(-1.165)\end{array}$ & $\begin{array}{c}0.015 \\
(-1.388)\end{array}$ & $\begin{array}{c}0.013 \\
(-1.174)\end{array}$ & & $\begin{array}{c}0.014 \\
(-1.573)\end{array}$ & $\begin{array}{c}0.012 \\
(-1.391)\end{array}$ & $\begin{array}{c}0.013 \\
(-1.557)\end{array}$ \\
\hline $\mathrm{FU}$ & & $\begin{array}{l}-0.0005 \\
(-0.243)\end{array}$ & $\begin{array}{l}-0.001 \\
(-0.664)\end{array}$ & $\begin{array}{c}-0.001 \\
(-0.503)\end{array}$ & & $\begin{array}{l}-0.0002 \\
(-0.103)\end{array}$ & $\begin{array}{c}0.0007 \\
(-0.448)\end{array}$ & $\begin{array}{c}0.001 \\
(-0.774)\end{array}$ \\
\hline GNB*DU & & & $\begin{array}{c}-0.014 * * * \\
(-2.770)\end{array}$ & & & & $\begin{array}{c}0.014 * * * \\
-3.69\end{array}$ & \\
\hline $\mathrm{GNB} * \mathrm{FU}$ & & & & $\begin{array}{c}-0.004 \\
(-0.667)\end{array}$ & & & & $\begin{array}{l}0.009 * * \\
(-2.049)\end{array}$ \\
\hline DV & $\begin{array}{c}-6.99 \mathrm{E}-11 \\
(-0.068)\end{array}$ & $\begin{array}{c}-1.74 \mathrm{E}-10 \\
(-0.167)\end{array}$ & $\begin{array}{c}-1.85 \mathrm{E}-10 \\
(-0.182)\end{array}$ & $\begin{array}{c}-2.06 \mathrm{E}-10 \\
(-0.197)\end{array}$ & $\begin{array}{c}1.60 \mathrm{E}-10 \\
(-0.194)\end{array}$ & $\begin{array}{c}1.80 \mathrm{E}-11 \\
(-0.022)\end{array}$ & $\begin{array}{c}2.90 \mathrm{E}-11 \\
(-0.037)\end{array}$ & $\begin{array}{c}9.48 \mathrm{E}-11 \\
(-0.115)\end{array}$ \\
\hline $\mathrm{MC}$ & $\begin{array}{c}2.87 \mathrm{E} 10^{* *} \\
(-2.003)\end{array}$ & $\begin{array}{c}2.64 \mathrm{E}-10 \\
(-1.819)\end{array}$ & $\begin{array}{c}2.81 \mathrm{E}-10^{* *} \\
(-1.989)\end{array}$ & $\begin{array}{c}2.59 \mathrm{E} 10^{*} \\
(-1.773)\end{array}$ & $\begin{array}{c}-1.48 \mathrm{E}-11 \\
(-0.130)\end{array}$ & $\begin{array}{c}-3.93 \mathrm{E}-11 \\
(-0.341)\end{array}$ & $\begin{array}{c}-5.70 \mathrm{E}-11 \\
(-0.519)\end{array}$ & $\begin{array}{c}-2.57 \mathrm{E}-11 \\
(-0.225)\end{array}$ \\
\hline AS & $\begin{array}{c}-1.66 \mathrm{E}-12 \\
(-0.796)\end{array}$ & $\begin{array}{c}-1.32 \mathrm{E}-12 \\
(-0.628)\end{array}$ & $\begin{array}{c}-6.66 \mathrm{E}-13 \\
(-0.322)\end{array}$ & $\begin{array}{c}-1.07 \mathrm{E}-12 \\
(-0.500)\end{array}$ & $\begin{array}{c}2.25 \mathrm{E}-12 \\
(-1.358)\end{array}$ & $\begin{array}{c}2.59 \mathrm{E}-12 \\
(-1.546)\end{array}$ & $\begin{array}{c}1.91 \mathrm{E}-12 \\
(-1.19)\end{array}$ & $\begin{array}{c}1.99 \mathrm{E}-12 \\
(-1.185)\end{array}$ \\
\hline DGDP & $\begin{array}{c}3.41 \mathrm{E}-14^{* *} \\
(-2.242)\end{array}$ & $\begin{array}{c}-6.55 \mathrm{E}-14 \\
(-0.731)\end{array}$ & $\begin{array}{c}-8.56 \mathrm{E}-14 \\
(-0.978)\end{array}$ & $\begin{array}{c}-6.59 \mathrm{E}-14 \\
(-0.734)\end{array}$ & $\begin{array}{c}1.50 \mathrm{E}-14 \\
-1.238\end{array}$ & $\begin{array}{c}-9.46 \mathrm{E}-14 \\
(-1.329)\end{array}$ & $\begin{array}{c}-7.38 \mathrm{E}-14 \\
(-1.086)\end{array}$ & $\begin{array}{c}-9.35 \mathrm{E}-14 \\
(-1.330)\end{array}$ \\
\hline FGDP & $\begin{array}{c}1.94 \mathrm{E}-15 \\
(-0.378)\end{array}$ & $\begin{array}{c}2.15 \mathrm{E}-15 \\
(-0.416)\end{array}$ & $\begin{array}{c}2.18 \mathrm{E}-15 \\
(-0.432)\end{array}$ & $\begin{array}{c}2.02 \mathrm{E}-15 \\
(-0.388)\end{array}$ & $\begin{array}{c}-5.52 \mathrm{E}-15 \\
(-1.348)\end{array}$ & $\begin{array}{c}-5.38 \mathrm{E}-15 \\
(-1.307)\end{array}$ & $\begin{array}{c}-5.40 \mathrm{E}-15 \\
(-1.380)\end{array}$ & $\begin{array}{c}-5.05 \mathrm{E}-15 \\
(-1.241)\end{array}$ \\
\hline $\mathrm{CD}$ & $\begin{array}{c}0.02 \\
(-0.882)\end{array}$ & $\begin{array}{c}0.021 \\
(-0.824)\end{array}$ & $\begin{array}{c}0.029 \\
(-1.141)\end{array}$ & $\begin{array}{c}0.024 \\
(-0.927)\end{array}$ & $\begin{array}{c}-0.012 \\
(-0.636)\end{array}$ & $\begin{array}{c}-0.012 \\
(-0.572)\end{array}$ & $\begin{array}{c}-0.019 \\
(-0.997)\end{array}$ & $\begin{array}{c}-0.019 \\
(-0.933)\end{array}$ \\
\hline Constant & $\begin{array}{c}-0.029 \\
(-0.519)\end{array}$ & $\begin{array}{c}-0.025 \\
(-0.441)\end{array}$ & $\begin{array}{c}-0.013 \\
(-0.234)\end{array}$ & $\begin{array}{c}-0.016 \\
(-0.280)\end{array}$ & $\begin{array}{c}0.031 \\
(-0.688)\end{array}$ & $\begin{array}{c}0.036 \\
(-0.805)\end{array}$ & $\begin{array}{c}0.024 \\
(-0.554)\end{array}$ & $\begin{array}{c}0.015 \\
(-0.337)\end{array}$ \\
\hline R-squared & 0.182 & 0.193 & 0.242254 & 0.196 & 0.198 & 0.214 & 0.294 & 0.24 \\
\hline F-statistic & $3.922 * * *$ & $3.197 * * *$ & $3.804 * * *$ & $2.908 * *$ & $4.347 * * *$ & $3.62 * * *$ & $4.962 * * *$ & $3.764 * * *$ \\
\hline
\end{tabular}

* significant at the $10 \%$ level $^{* *}$ significant at the $5 \%$ level ${ }^{* * *}$ significant at the $1 \%$ level

If the presence of a wide digitization gap between the home and host countries, it is difficult for an acquiring firm to reconfigure the network in order to access the core knowledge it needs to promote innovation; however, if the digitization gap is narrow, an acquiring firm may be able to reconfigure its global value network by taking advantage of the host country's digitization advantage. Thirdly, digitization fundamentally separates the flows of information and service from 
How Do Cross-Border Mergers and Acquisitions Improve Innovation Quality in Emerging Market Multinational Enterprises? An Interaction Perspective Based on Network Balance and Digital Gaps

physical-product flow, as an enterprise's core knowledge is embedded in a digital platform or a service-oriented business model, rather than in physical assets. This increases the separation between products and services. The digital gap thus makes it difficult for the acquirer to connect with the target firm.

\section{(2) Grouping according to overseas knowledge complexity}

Knowledge complexity is the degree of diversity in the disciplines that are required for knowledge development. Based upon the conclusions of a textual analysis (Patel et al.,2014), examples of high knowledge complexity industries are those that develop paper machines, mobile phones, and generators; manufacture cruise ships, aircraft, automobiles, and pharmaceuticals; and design software. All other industries are classified as low knowledge complexity. The grouping of this study's empirical results in Table 5 indicates that, for Chinese manufacturing enterprises, a balanced network is more advantageous when the acquiring firm belongs to a low knowledge complexity industry. However, in instances of high knowledge complexity, the digitization levels of both the home and host countries can positively moderate the correlation between network balance and innovation; these conditions are conducive to the cultivation of international innovation. This is because highly complex and non-transferable tacit knowledge is the source of enterprises' core competitive advantages, whereas the advantages of the Chinese manufacturing industry are concentrated in ease of coding, simple standardization, and scale. Thus, Chinese firms can effectively transform and use only low complexity international knowledge. Digitization improves the standardization, simplification, openness, and transferability of tacit knowledge; thus, it can help Chinese enterprises to acquire highly complex tacit knowledge.

DOI: $10.24818 / 18423264 / 53.3 .19 .12$ 
Fei Li, Yan Chen, Liyezi Zhang, Lavinia Dudaş

Table 4. Results grouped by digital gapwidth

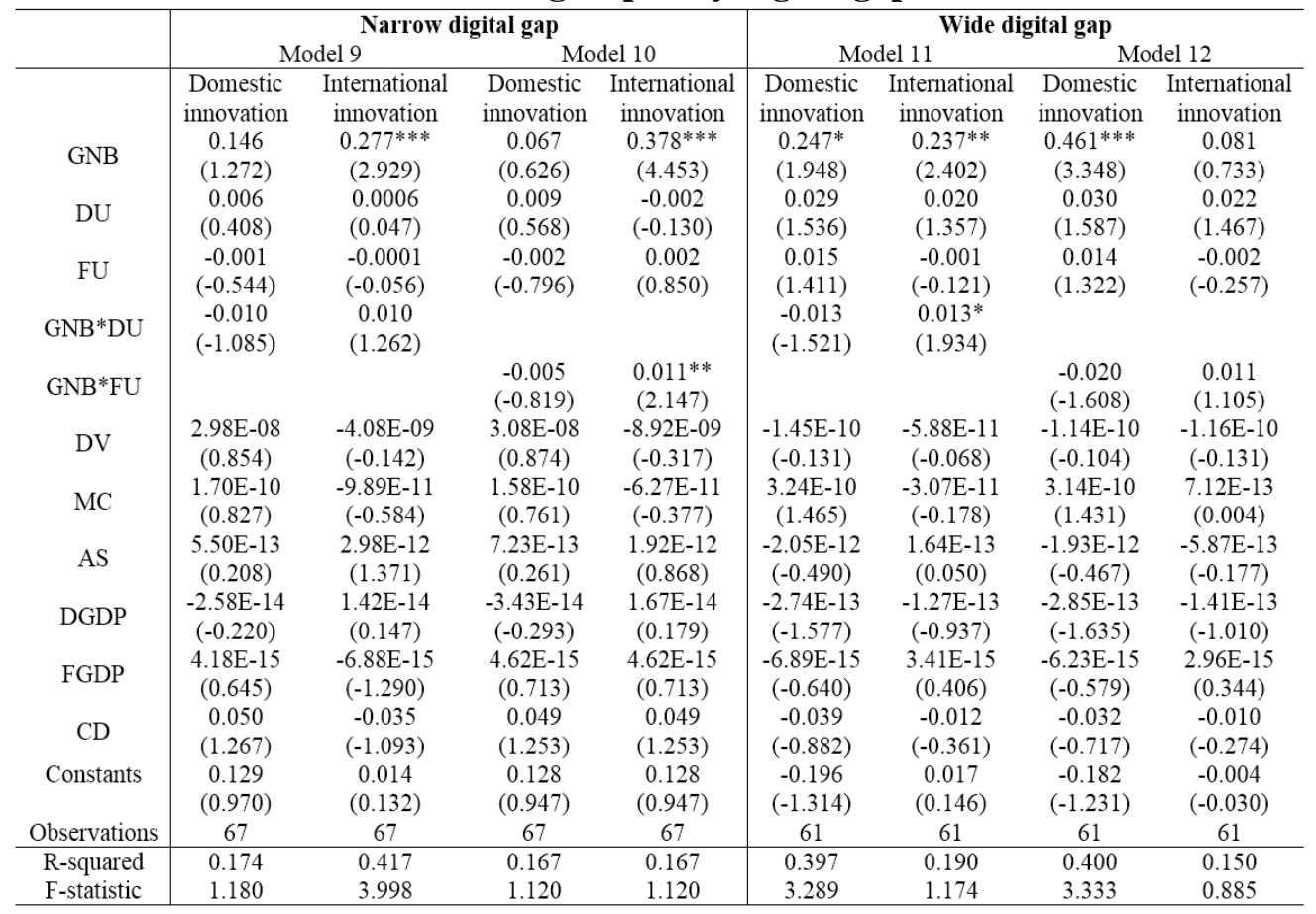

Notes:* significant at the $10 \%$ level** significant at the $5 \%$ level*** significant at the $1 \%$ level

Table 5. Results grouped by overseas knowledgecomplexity

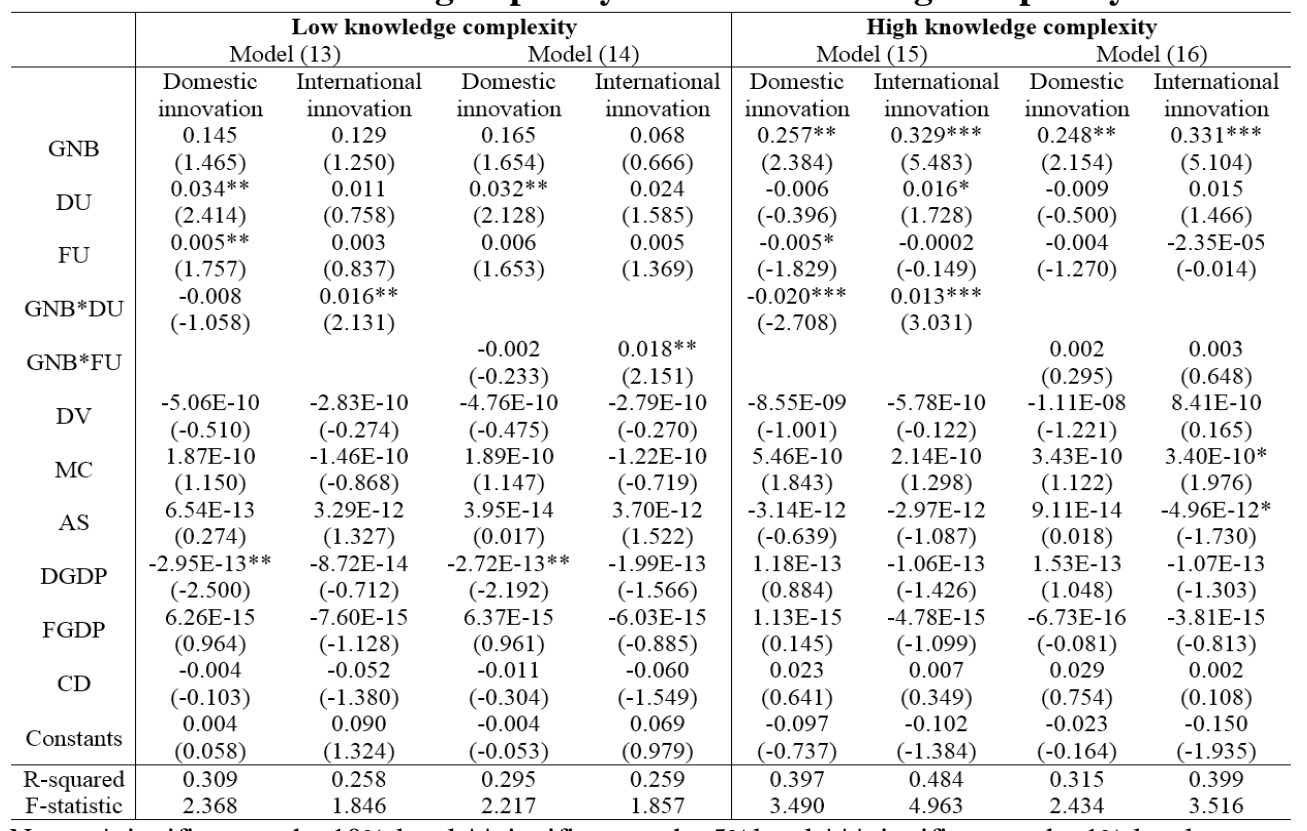

Notes: *significant at the $10 \%$ level **significant at the $5 \%$ level $* * *$ significant at the $1 \%$ level.

DOI: $10.24818 / 18423264 / 53.3 .19 .12$ 
How Do Cross-Border Mergers and Acquisitions Improve Innovation Quality in Emerging Market Multinational Enterprises? An Interaction Perspective Based on Network Balance and Digital Gaps

\subsection{Robustness check}

\section{(1) Bootstrap repeated-sampling test}

The results of the bootstrap repeated-sampling method are shown in Table 6, which shows that all of this study's empirical results are robust. To make up for the small sample size, we applied a data set calculated using the bootstrap method to reflect the sampling distribution of each statistic. This method approximates the statistic's value and confidence interval, as well as the quantile corresponding to the same confidence level, and was also used to test the hypotheses. Therefore, the bootstrap method solved many problems that traditional statistical-analysis methods could not. Bootstrapping is a non-parametric inference method that can be applied via computer simulation when the distribution or analytical formula of a data set is uncertain.

The hidden information can be extracted and more accurate confidence intervals can be calculated by resampling the observed samples. In this paper, we used bootstrap samples that were set to 500 times; the bias-correction interval was $95 \%$ and bilateral.

\section{Table 6. Bootstrap test results}

\begin{tabular}{ccccc}
\hline Path & Estimate & Lower & Upper & P \\
\hline Network balance $\rightarrow$ domestic innovation quality & 0.273 & 0.157 & 0.398 & $0.003^{* * *}$ \\
Network balance $\rightarrow$ international innovation quality & 0.23 & 0.128 & 0.34 & $0.003^{* * *}$ \\
$\begin{array}{c}\text { Network balance * Digitalization of home country } \\
\text { domestic innovation quality }\end{array}$ & -0.1 & -0.19 & -0.01 & $0.027^{* *}$ \\
$\begin{array}{c}\text { Network balance * Digitalization of home country } \rightarrow \\
\text { international innovation quality }\end{array}$ & 0.014 & 0.007 & 0.022 & $0.003^{* * *}$ \\
$\begin{array}{c}\text { Network balance * Digitalization of host country } \\
\text { international innovation quality }\end{array}$ & 0.011 & 0.003 & 0.019 & $0.009^{* * *}$ \\
$\begin{array}{c}\text { Network balance * Digitalization of host country } \\
\text { domestic innovation quality }\end{array}$ & -0.001 & -0.01 & 0.008 & 0.885 \\
\hline
\end{tabular}

\section{(2) Substitute variable: Network-balance and digitization level}

In calculating network efficiency, we used the number of cooperative patents filed by the acquiring firm with universities and subsidiaries within its group; the number filed with other companies outside its group was an alternative variable. We recorded the network balance, X1, as a substitute variable for GNB; the regression results show that the first two variables relate to domestic innovation quality, and the last two relate to international innovation quality. We then replaced the moderating variables with the rate of fixed broadband subscriptions(per 100

DOI: $10.24818 / 18423264 / 53.3 .19 .12$ 
Fei Li, Yan Chen, Liyezi Zhang, Lavinia Dudaş

people) in the home and host countries. The empirical results are robust ${ }^{1}$.

\section{Discussion and Conclusion}

In this study, we conducted a bootstrap repeated-sampling analysis of a sample of 146 overseas M\&As conducted by Chinese-listed manufacturing companies between 2001 and2016. We found that network-embedding balance has a positive impact on the quality of domestic and international innovations in the wake of M\&As and that China's digital development has not promoted a positive correlation between network balance and innovation quality. In the presence of a wide digital gap between a firm's home and host countries, network balance can significantly improve the quality of domestic innovation in the wake of an overseas M\&A; conversely, when this gap is narrow, a firm can use the interaction between network balance and the host country's digital level can to improve the quality of its international innovation.

This study makes several academic contributions. Firstly, instead of only examining the firm-specific advantages of EMNEs in the digital economy, it used the interactions of digital gaps and network balance to explore a new mechanism by which such enterprises construct balanced networks to realize global innovation advantages in the digital economy. Secondly, instead of relying on overseas M\&A theory (in which the relationship between isolated M\&A parties is thought of only as binary), it based itself on global network embedding theory and focussed on how the balance between the acquiring firm's domestic and foreign networks enhances its global innovation advantage once it has engaged in an overseas M\&A. Thirdly, in terms of digitization, it examined both the developed countries' ability to provide digital location advantage and the emerging markets' influence on their home countries' digital advantage. Finally, from the perspective of the digital gap that exists between the host and home countries, we explore how the differences and similarities in digital-location advantages between the host and home countries can moderate the influence wielded by network balance on overseas M\&A innovation quality.

\section{ACKNOWLEDGMENTS}

This work was supported by a grant of Ministery of Research and Innovation, CNCS - UEFISCDI, project number PN-III-P1-1.1-PD-2016-0780, within

PNCDI III. Lavinia Dudaş acknowledges the financial support.

${ }^{1}$ Due to space limitations, the results of this study are not shown in the paper. Readers may apply for them to the author if necessary. 
How Do Cross-Border Mergers and Acquisitions Improve Innovation Quality in Emerging Market Multinational Enterprises? An Interaction Perspective Based on Network Balance and Digital Gaps

\section{REFERENCES}

[1] Ahammad, M. F. , Tarba, S. Y. , Liu, Y. \& Glaister, K. W. (2014), Knowledge Transfer and Cross-Border Acquisition Performance: The Impact of Cultural Distance and Employee Retention.International Business Review, 25, 66-75;

[2] Alcácer, Juan, Cantwell, J. \& Piscitello, L. (2016),Internationalization in the Information Age: A New Era for Places, Firms, and International Business Networks? Journal of International Business Studies, 47, 499-512;

[3] Bharadwaj, A. \& Pavlou, P. A. (2013),Digital Business Strategy: Toward a Next Generation of Insights. Mis Quarterly, 37, 471-482;

[4] Brouthers, K., Geisser, K.\& Rothlauf, F. (2016),Explaining the Internationalization of $\boldsymbol{i}$ Business Firms. Journal of International Business Studies, 47, 513-534;

[5] Chen, F. , Li, F. \& Meng, Q. (2017),Integration and Autonomy in Chinese Technology-Sourcing Cross-Border M\&As: From the Perspective of Resource Similarity and Resource Complementarity.Technology Analysis \& Strategic Management, 29,1002-14;

[6] Coombs, J. E. , Deeds, D. L. \& Ireland, R. D. (2009), Placing the Choice between Exploration and Exploitation in Context: A Study of Geography and New Product Development. Strategic Entrepreneurship Journal, 3, 261-279;

[7] Freeman C.(1991), Network of Innovators: A Synthesis of Research Issues. Research Policy 20, 499-514;

[8] Graebner, M. E., Heimeriks, K. H., Huy, Q. N. \& Vaara, E. (2017),The Process of Postmerger Integration: A Review and Agenda for Future Research. Academy of Management Annals, 11, 1-32;

[9] Herrigel, G. , Wittke, V. \& Voskamp, U. (2013),The Process of Chinese Manufacturing Upgrading: Transitioning from Unilateral to Recursive Mutual Learning Relations. Global Strategy Journal, 3, 109-125;

[10] Iurkov V, Benito G.(2018), Domestic Alliance Networks and Regional Strategies of Mnes: A Structural Embeddedness Perspective.Journal of International Business Studies, 49, 1033-59;

[11] Kobrin S J.(2017), Bricks and Mortar in a Borderless World: Globalization, the Backlash, and the Multinational Enterprise. Social Science Electronic Publishing, 7, 159-71;

[12] Lavie D, Miller S (2008), Alliance Portfolio Internationalization and Firm Performance.Informs, 19, 623-46;

[13] Liang, C. , Noman, S. , Jingtao, Y. \& Sali, L. (2018), The International Penetration of Ibusiness Firms: Network Effects, Liabilities of Outsidership and Country Clout.Journal of International Business Studies;

DOI: $10.24818 / 18423264 / 53.3 .19 .12$ 
Fei Li, Yan Chen, Liyezi Zhang, Lavinia Dudaş

[14] Makri M, Hitt M. A., Lane P. J.(2010), Complementary Technologies, Knowledge Relatedness, and Invention Outcomes in High Technology Mergers and Acquisitions. Strategic Management Journal, 31, 602-28;

[15] Manyika J., Lund S., Bughin J., et al.(2016), Digital Globalization: The New Era of Global Flows. McKinsey Global Institute San Francisco;

[16] Nambisan, \& Satish (2018).Architecture vs. ecosystem perspectives: reflections on digital innovation. Information and Organization, 28, 104-106.

[17] Patel P. C., Fernhaber S. A., Mcdougall;Covin P. (2014), Beating Competitors to International Markets: The Value of Geographically Balanced Networks for Innovation. Strategic Management Journal, 35, 21-30;

[18] Pezderka, N. \& Sinkovics, R. R. (2011), A Conceptualization of E-Risk Perceptions and Implications for Small Firm Active Online Internationalization.International Business Review, 20, 409-422;

[19] Puranam, P. \& Chaudhuri, S.(2009), Integrating Acquired Capabilities: When structural Integration is (un)necessary. Organization Science, 20, 313-328;

[20] Rai, A. , Pavlou, P. A. , Im, G. \& Du, S. (2012), Interfirm it Capability Profiles and Communications for Cocreating Relational Value: Evidence from the Logistics Industry. MIS Quarterly, 36, 233-262;

[21] Williamson, \& Peter, J. (2016), Building and Leveraging Dynamic Capabilities: Insights from Accelerated Innovation in China. Global Strategy Journal, 6, 197-210;

[22] Yoo Y, Henfridsson O, Lyytinen K.(2010), Research Commentary-The New Organizing Logic of Digital Innovation: An Agenda for Information Systems Research. Information systems research, 21, 724-35;

[23] Yoon, H. and J. J. Lee (2016),Technology-acquiring Cross-border M\&As by Emerging Market Firms: Role of Bilateral TradeOpenness.Technology Analysis \& Strategic Management, 28, 251-265;

[24] Zhang, J. , Ahammad, M. F. , Tarba, S. , Cooper, C. L. , Glaister, K. W. , and Wang, J. (2015), The Effect of Leadership Style on Talent Retention During Merger and Acquisition Integration: Evidence from China. The International Journal of Human Resource Management, 26, 1021-1050;

[25] Zou, H. \& Ghauri, P. N. (2008), Learning through International Acquisitions: The Process of Knowledge Acquisition in China.Management International Review, 48, 207-226. 